\title{
What on Earth! Slated Globes, School Geography and Imperial Pedagogy
}

Mahshid Mayar

\section{(2) OpenEdition \\ Journals}

Electronic version

URL: https://journals.openedition.org/ejas/15703

DOI: 10.4000/ejas. 15703

ISSN: 1991-9336

Publisher

European Association for American Studies

\section{Electronic reference}

Mahshid Mayar, "What on Earth! Slated Globes, School Geography and Imperial Pedagogy", European journal of American studies [Online], 15-2 | 2020, Online since 17 November 2020, connection on 08 July 2021. URL: http://journals.openedition.org/ejas/15703 ; DOI: https://doi.org/10.4000/ejas.15703

This text was automatically generated on 8 July 2021 .

Creative Commons License 


\title{
What on Earth! Slated Globes, School Geography and Imperial Pedagogy ${ }^{1}$
}

\author{
Mahshid Mayar
}

\section{Introduction}

1 In 1576, the English explorer-turned-pirate Martin Frobisher (1535-1594) traveled to America (Chaves et al. xxiv). Among his belongings was a blank globe onto which he was going to carve cartographic findings as he explored the "New World." Three centuries later, "slated globes"-blank, black table globes that could be written on by chalk or crayon-were advertised in the 1876 edition of The Cyclopcedia of Education (372) as ideal tools to teach a wide range of neighboring subjects: "advanced geography, ... spherical geometry, trigonometry, navigation, etc." Right in the middle of the twentieth century, the Social Studies for Teachers and Administrators (328) commended slated globes as support material for teaching geography at all levels: "This simplified globe is excellent for elementary geography exercises, as well as being ideal for projects at intermediate and upper-grade levels." By this time, and in the country's competitive cartography market, American educators and globe-making companies such as Denoyer-Geppert and Co. and Rand McNally and Co. began to call them by a variety of names: "write-on-me," "learn-by-doing," "simplified," or "project problem slated" globes. ${ }^{2}$

Outside the United States too, slated globes were known by many names, from "Induktion-" or "Anleitungglobus" in Germany and Austria to chalkboard "slated globes" and "slated outline globes" in England. Records suggest that blank globes had been invented in Britain and Germany almost at the same time when Americans stumbled upon the idea. The so-called Induktionglobus $(32.5 \mathrm{~cm}$ in diameter) invented by Joseph August Brandegger (1797-1890) in the second half of the nineteenth century is one example of European slated globes that, unlike their American counterparts, 
were used to teach both terrestrial and celestial geography to German and Austrian pupils (Mokre 78-9). In England, too, the 1846 edition of A Concise Introduction to the Knowledge of the Globes mentioned slated globes, examples of which were produced by Malby \& Co. (Houghton Street, Newcastle Street, Strand, London), as useful tools in teaching "the young student... the position of the principal places on the surface of the Globe (Maynard 73)." A later example of British slated globes from 1906, manufactured by George Philip and Son, the London Geographical Institute, was listed in the institute's own publication, Geographical Gleanings (Burrows 80). Like other British slated globes I have come across, this specimen too was manufactured with the outlines of the continents already printed on its surface. Similar examples of British slate surface globes were mentioned in the 1906 edition of the Journal of Education: A Monthly Record and Review, again all outlined (Rice 202).

Invested in the many intended and potential uses of the completely blank, USmanufactured slated globes as objects in the United States' imperial archive, and at the risk of glossing their uses in European school- and war-rooms, ${ }^{3}$ I leave a more comprehensive examination of slated globes' multiple origins and uses in other settings to historians of European geography. Furthermore, given the dearth of historical studies concerning the invention and uses of slated globes, I concede that to do the subject matter justice will take further archival studies by historians of geography as well as historians of education. Nonetheless, I take the occasion here to briefly investigate the American origins of slated globes, examining their growing popularity over the course of the nineteenth and twentieth centuries in teaching $4^{\text {th }}, 6^{\text {th }}$, or $10^{\text {th }}$ grade American pupils "certain fundamentals" of world geography (Geppert 8). Delving into the study of these historical artifacts, I focus the paper on the examination of slated globes as ideological tools of empire that taught American children not only how to draw maps but also, far more significantly, how to see the world. In this part, I identify slated globes' potential capacity at the service of the geopolitical interests and spatial urgencies of the young US Empire and as spaces where American pupils of all grades, the future stewards of the rising US Empire, could re-imagine and re-order the world. The legitimacy of any such inquiry into geographical tools' potential metageographical uses lies in the fact that, as map historian John Brian Harley argues in his discussion of the simultaneously practical and ideological nature of maps, "that which is absent from a map is as much a proper field for inquiry as that which is present" (86). Along this line, I then proceed to a theoretical discussion of cartographic blank as alluring, pliant, communicative, and performative of political meaning, reading slated globes as generative of an alternative type of terra incognita.

\section{Slated Globes: An American Genealogy}

4 The earliest US-made slated globes that I have found record of appear to have been manufactured by the Boston-based globe-maker Josiah Loring (ca. 1775-1840). Described as a sine qua non in American schoolrooms, Loring's "blank globes" (either black or ivory in color) were advertised as pedagogical novelty in the December 1831 issue of the American Annals of Education and Instruction (174). Hazard's Register of Pennsylvania, Volume 12 (355) commended Loring's blank globes as specially outstanding artifacts in his rather substantial globe inventory. Almost two decades forward, a different line traces back to a slated globe patented by Forrest Shepherd on December 
22, 1857 (Figure 1). Shepherd's slated globe (Patent No. 18,931) applied "elastic slate" to an orb, making a simple slated globe for classroom use. ${ }^{4}$ The 1859 volume of The Connecticut Common School Journal ( (Barnard 311) quoted Tutor Kelsey of Amher st College who praised Shepherd's slated globes despite their high prices, stating that "[w]e should consider our recitation rooms poorly furnished without these Globes." The 1876 edition of Knight's American Mechanical Dictionary, however, merely mentioned Shepherd's or perhaps another slated globe of similar make as "[a] paper shell globe covered in powdered slate," without providing any further details as to its origins, use, or popularity (Knight 987).

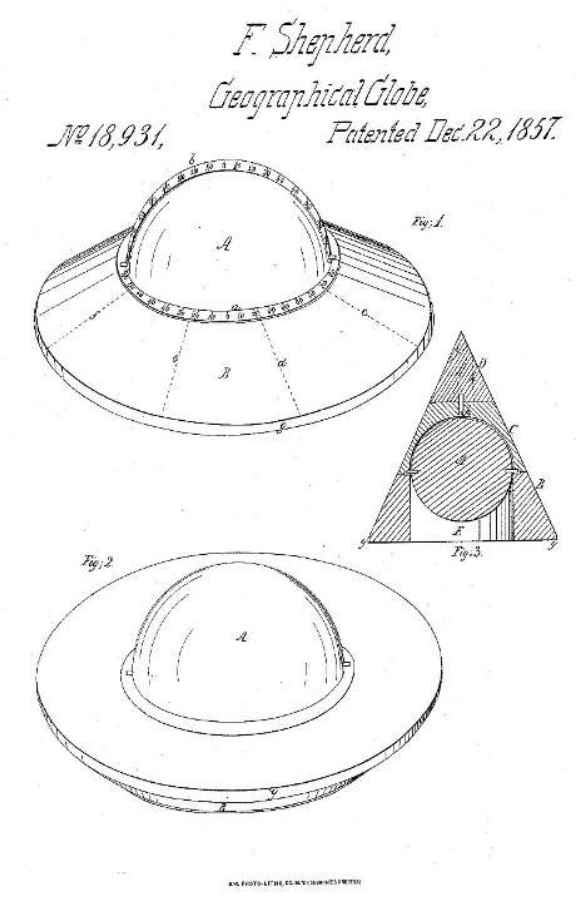

Figure 1. Slated Globes, manufactured and patented by Forrest Shepherd on December 22, 1857 - Patent No. 18,931. Source: United States Patent and Trademark office, www.uspto.gov.

It was in fact only toward the end of the century that, with the invention of a more practical slated globe, these artifacts finally gained currency in American schools. On May 1, 1894, Isaac and Mary Ann Hodgson, of Chicago, Ill., obtained the patent (No. 519,061 ) for their "Geographical Globe" (Figure 2). The globe they had invented consisted of two layers, an inflatable core made of India-rubber and "an exterior globe or sphere made of cloth or suitable material to be used as a slated or black-board on which may be drawn a representation of the geography of the world and erased therefrom." ${ }^{\prime 5}$ Right before the turn of the twentieth century, and as these artifacts proliferated and their use proved of immense benefit in teaching world geography, it was recommended to geography teachers to either use a slated globe or-in case of a tight budget, especially in schools in the countryside-to at least bring an orange or an apple to the class in order to teach primary-school geography lessons (King 397).

While in the 1850s a map-making company such as Moore and Nims, of Troy, NY, would simply advertise their slated globes in educational journals with their prices listed (30 and 16 inch for $\$ 40$ and $\$ 12$, respectively), to which it was plainly added that they "are 
intended for exercise in map drawing" (Davis 232), in the 1910s and 1920s Rand McNally and Co., for one, would advertise their "Slated Table Stand Globes" as indispensable classroom equipment (Rand McNally and Co. 15). Improved over time for use by generations of students and still popular in the mid-twentieth century, slated globes in different makes and sizes had become so popular and so affordable that even the Bureau of Indian Affairs, Department of the Interior, began in the 1950s to recommend two types of 16" Denoyer's project-problem slated outline globes for use in the nation's least-funded “Indian schools (United States Bureau of Indian Affairs 94)."

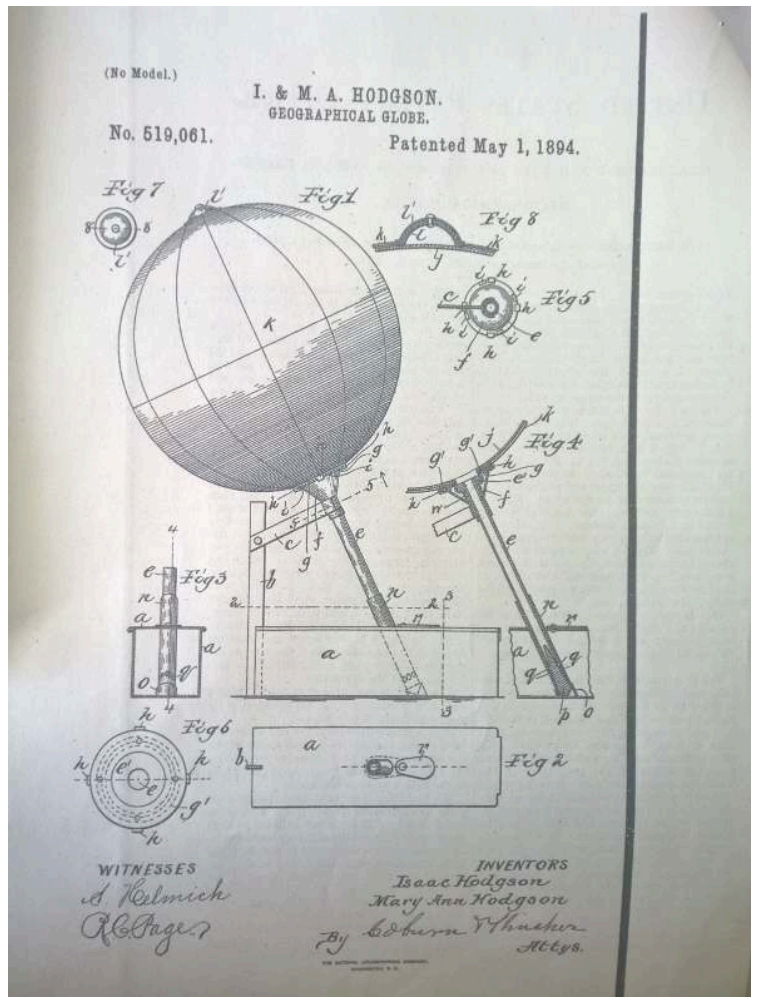

Figure 2. Slated globes, manufactured and patented by Isaac and Mary Ann Hodgson on May 1, 1894 - Patent No. 519,061. Source: United States Patent and Trademark Office, www.uspto.gov.

7 As noted before, slated globes seem to have had as many origin stories as names. And yet, early-twentieth century American journals of education advertised slated globes as novelties in American school geography either because they were unaware of the parallel inventions in Europe or-since they time and again referred to Shepherd as the original inventor-they had decided to avoid giving European globe-makers any credit. ${ }^{6}$ Remarkably, this attitude was contradicted by a story of an altogether different nature that was told of these globes' origins in the middle of the twentieth century. In 1955, Otto E. Geppert, cofounder of the map-making company Denoyer-Geppert and Co., started the promotional essay the company had dedicated to slated globes with the following words:

More than 15 years ago we were getting calls from a few progressive educational centers for a special type of globe. At that time it was not made in our country. It was made in England. Evidently some of our elementary school teachers and supervisors of elementary education had been visiting English schools and seeing how effective this type of globe was for teaching earth or world geography in the lower grade levels, they insisted on getting that type of globe and nothing else. The globe in question was only a little more than 12 " in diameter. It was made of wood 
painted black, with the continents rather crudely outlined in a thin line of white ink or paint. Certainly nothing to get enthusiastic about-until one found out how it was used: For this small, rather crude globe without a meridian, just a plain axis mounting, schools willingly paid from $\$ 30.00$ to $\$ 35.00$. (8)

Regardless of the various, and at times contradictory, origin stories of slated globes that different sources tell and their itinerary before they ended up in schoolrooms across the United States, it is evident that these globes became truly popular with American geography teachers in the twentieth century, resulting in a competitive market in which companies such as Denoyer-Geppert tried to take credit for their introduction to the US market.

\section{Slated Globes at the Dawn of the American, aka, the Geographic Century}

9 In the spirit of what she calls "pedagogic modernity," Sumathi Ramaswamy (29-30) makes the case for terrestrial globes as quintessentially imperial objects-objects that materialized "a planetary consciousness grounded in Earth's sphericity." Indeed, terrestrial globes have long been tools at the service of imperial geographical education. As I demonstrate here, as artifacts of great ideological import in the archives of the rising global empire, slated globes offered an even more enterprising possibility than did terrestrial globes as their predecessors, that is, to re-imagine the planetary consciousness that terrestrial globes helped teach, all over again. ${ }^{7}$ Produced by globemaking companies, such as A. J. Nystrom and Co. (1903-present), Rand McNally and Co. (1856-present), Denoyer-Geppert and Co. (1916-1980s), Weber Costello (1907-1960), and others in the United States, these artifacts were tools with which to imagine the world afresh as a homogeneous whole, albeit one which offered a colonially creative "spatial void" on which teachers and students of geography could draw borders and navigation routes with crayon or chalk without the fixity of an already illustrated and ornamented terrestrial globe (Rand McNally and Co. 15). More affordable than fully illustrated terrestrial globes (Figure 3), ${ }^{8}$ slated globes had come to offer "unlimited possibilities" in teaching world geography to American children (Rand McNally and Co. 15). In sum, put to use in teaching world geography to more advanced students, and responding to major changes in geography as both a school subject and an imperial project, slated globes espoused the cause of empire with that of public education. But what were these changes and in what ways did they affect the uses of slated globes in American classrooms? 


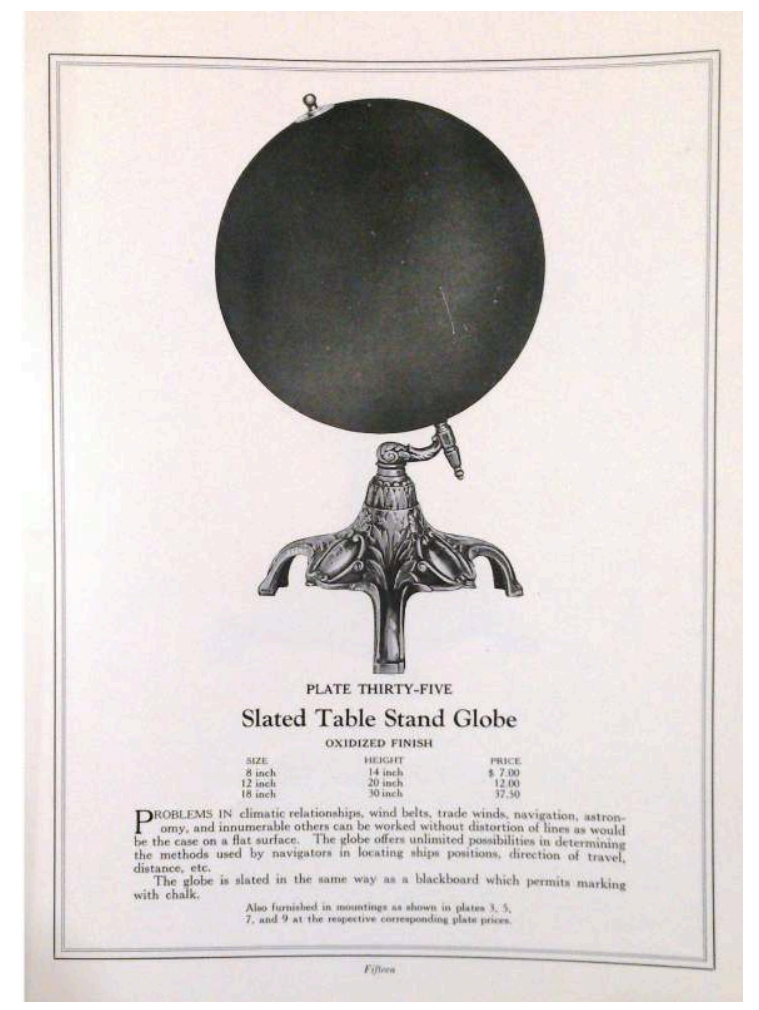

Figure 3. Slated Table Stand Globe, manufactured by Rand McNally and Co., ca. 1910s. Courtesy The Newberry Library, Chicago.

By the dawn of a century christened as both the American and the geographic century, and on the eastern side of the Atlantic, European maps and globes overflowed with cartographic data, various shades of imperial colors, and contested colonial placenames. By this time, European explorers and cartographers actively filled the last remaining terrae incognitae with ever more dots, lines, and words, so much so that maps and globes hardly showed any remarkably large bare surfaces. Apace with the newest discoveries and explorations, maps and globes had to be continuously updated to keep up with the latest changes European imperialism dictated upon the face of the earth. Moreover, the vanishing of the terra incognita, of the antipodes, Africa, and elsewhere, meant that-ever so anxious as cartographers now were about "mak[ing] sense of what the new replete mapping of the world means" (Smith 54)-new definitions of geography and cartographic practices were needed. Consequently, as geography "adopted a new and more intricate identity" (Smith 54), geographers in and out of schools took part in projects that collected, classified, and updated geographical data about the previously "unknown," de-mystified the terra nondum cognita (territory not yet known), and excited economic and political interest in near and far parts of the world and their markets. As imagined by European colonizers and reflected in ambitious cartographic projects such as the "Millionth Map" proposed by Albrecht Penck (1858-1945) in 1891, this world was deemed a sufficiently homogeneous entity, to be neatly knit into a global network of inter-imperial exchanges. ${ }^{9}$

In other words, by the dawn of the twentieth century, European empires celebrated their centuries-long colonization projects that had resulted in a massive quilt of terrae cognitae that, with the exception of a few spots here and there, had turned the world into an illusively homogeneous totality. In other words, from a Western point of view and-at least among the white, free populations of various Western metropoles-as a 
result of centuries of colonial practices, the world was assumed ready to be imagined as a market of overlapping spaces where the colonizers could pursue an assortment of projects toward the colonized: to dominate and exploit or to educate and elevate. In light of such make-believe homogeneity, Europeans could make sense of their modern lives only through an awareness of their interdependence on a web of inter-imperial connections (Jameson 411). It was a life that, while unique to imperial subjects, was by no means isolated and abstracted from what resided beyond the borders of their immediate locality. Thus, early twentieth-century European cartography constituted of scientific and educational maps and globes that established one single imaginary of the world, a unitary planetary consciousness, which, from the perspective of the Western metropole, stood as a meticulously surveyed global environment.

On the Western side of the Atlantic, on the other hand, maps and globes heralded, braced, and promoted the expansionist projects of the final years of the century-a century of national coming of age for the United States, during which Americans had struggled to make sense of the nation's history and their spatially unsettled, globalizing empire. Around the turn of the twentieth century, Americans viewed maps and globes, Susan Schulten reminds us, as "arbiters of power" (5). Slated or replete, they were viewed as artifacts whose malleability in the hands of the present and future agents of empire marked the hand-in-glove advancement of the cause of their modern empire and of governance-minded cartographic matter (Akerman). Drawing a direct line between geography and wars of empire, President McKinley, for instance, told an audience of missionaries from the Methodist Episcopal Church that, once his prayers to God about the "Filipino question" had been answered, his first presidential order was for "the chief engineer of the War Department (our map-maker) to put the Philippines on the map of the United States" (Rusling 17).

13 As this incident attests, the popularity of slated globes in American classrooms coincided with a phase during which the United States, hoping to materialize the "global Monroe Doctrine," was actively redefining its standing as an imperial power beyond the Americas (Smith 5). The turn of the twentieth century was in fact the first of several "formative moments" that Smith has identified "in the US rise to globalism," spanning the years between the "classically colonial wars of 1898 " and the entry of the United States into World War I (Smith 5). Amid climactic changes in the modes and means of world cartography, Americans' heightened interest in and engagement with the world at large coincided with a turn-of-the-century crisis of legitimacy among European empires, ${ }^{10}$ as a result of which the formerly isolationist Americans viewed the world more as a web of seamlessly interrelated spaces. This meant that American geographers, in and out of schoolrooms, needed to pay special attention both to the rapidly disappearing terra incognita and to those recently-made-cognita regions (such as the Philippines, Hawaii, Guam, and Puerto Rico) that now stood in a different relationship to the United States. Consequently, by the end of the century, even the most mundane aspects of Americans' lives were mapped onto a cartographically known, commercially accessible, cognitively smaller world. As Du Bois maintained in his 1898 commencement address at Fisk University,

On our breakfast table lies each morning the toil of Europe, Asia, and Africa, and the isles of the sea; we sow and spin for unseen millions, and countless myriads weave and plant for us; we have made the earth smaller and life broader by annihilating distance, magnifying the human voice and the stars, binding nation to nation, until today, for the first time in history, there is one standard of human culture as well in 
New York as in London, in Cape Town as in Paris, in Bombay as in Berlin. (Du Bois and Provenzo 205) maps and terrestrial globes cast a near total eclipse over them, a cartographic masquerade resulting from spatial omniscience (or the delusion thereof). In response to this masquerade and along with the young empire's geopolitical urgencies noted above, a rather curious turn occurred in the United States. It is true that, during the final decades of the nineteenth century, data from discoveries and explorations in Africa and elsewhere had resulted in such excess of toponyms, routes, and borderlines that American geographers joined Europeans in celebrating the fact that there was no more need to "place elephants for want of towns" to fill the terra incognita on maps and globes (Swinton iv). What is more, while European colonizers posed as authors and, later, as readers of a material, objectified, plastic world that they were actively giving shape to and "writing" on through ongoing colonization projects, American cartographers reacted to the impending total loss of terra incognita in a manner fitting their role as agents of a rising empire: longing to assert their own reading of the world at large, and in the face of the so-called closing of the western frontier, the new imperialists embraced the new, replete blank that had resulted in part from the cartographic masquerade of colonization, welcoming slated globes as spaces of pragmatic emptiness and as tools with which to tilt away from then common cartographic traditions.

15 Therefore, the appeal of slated globes lay, I argue, in the fact that they could allow American youth, the future agents of the US empire, to learn to embrace the world afresh as a blank sphere onto which unprecedented orders, color codes, and borders could be dictated. If by then the earth was about to suffocate underneath the weight of cartographic facts and geographic knowledge, slated globes could help strip terrestrial globes of their imposed content, recasting them as a new "blank" of a different quality, an unornamented, unslathered homogeneity of another kind-performing an omission by design ${ }^{11}$ In other words, while the terrestrial globe-continually updated to keep up with the newest conquests over the terra incognita-paid homage to the colonial projects of expansion aggressively pursued by European empires and closely followed by the agents of the US empire, slated globes supported the young US empire's need to dismiss and downplay European colonial competition by imagining the world as one homogeneously re-inscribable blank.

As Edney contends (cf. Brückner 13-14), modern empires are cartographically constructed, and thus, their movements within and in between the spaces they dominate, exploit, or covet necessitate repeated acts of mapping (45). In other words, empires conduct their own surveying and develop their own mapping discourses and cartographic apparatus, regardless of (though heavily informed by and carefully positioned against) the maps they inherit from a former or neighboring empire or they seize from the native populations whose territory they plan to colonize. As citizens of a late-coming empire, Americans too were eager to draw their own maps of the world, inscribing it in their own "imperial vernacular" (Edney 45). In light of this, we should read slated globes as the scaled-down materialization of Americans' desire to imagine and map the world and develop their own cartographic narratives of the world while distancing themselves from European cartographic precedents. ${ }^{12}$ With slated globesmore widely in use in American schools during the first half of the twentieth centuryAmerican youth could re-draw and re-order the world in the US imperial vernacular. 
As such, slated globes should be viewed, if not as projections into a future that the comparatively young US empire envisioned for itself, then at least as modern, practice fields of world geography at the service of the urgent, shifting global interests of this outward-looking empire. After all, as Harley maintains, maps and globes have long been "appropriated as an intellectual weapon of state system" (88).

\section{Terra Incognita Iterum, the New Cartographic Blank}

Shifting focus from imperial geopolitics in the abstract back to the very surface of slated globes in American schoolrooms, it might seem at first sight as if slated globes were educational aid materials that served as practice fields to teach the basics of world geography to very young pupils in their first encounters with the subject: "Sometimes," wrote Otto E. Geppert, "I refer to this globe as similar to a storage battery. Looking at a storage battery we do not see very much, but," he continued, "it has a remarkable potential. It starts the car motor, it lights the lights, it plays the radio" (9). In line with Geppert's observations here, my reading of the potential uses of slated globes at more advanced levels of school geography, captures the nature of their intellectual repurposing and their ideological power to call back an intentional overall blankness imposed on the surface of the earth, enabling cartographic adventure and territorial domination. After all, as Geppert posits, once the slated globe is put to use, what geographical "things" happen and what they mean "is up to you" (9).

It is further evident that slated globes stand in a long line of objects that reflect a postEnlightenment fixation on the idea of blank. In effect, the post-Enlightenment West has hardly ceased to be fascinated by blank as (a) an unusually powerful metaphor (the notion that the human brain is a blank slate onto which impressions can be made through parenting, education, and other forms of exposure is an infamous example already):13 (b) a precondition to gendered and romanticized relationships between individuals and entities (the marginalized and disempowered figure of the female as well as non-female, infantilized bodies of native populations who have time and again been depicted in literature and political discourses as blank); ${ }^{14}$ and, (c) a spatial imaginary that comes with corresponding ideas and artifacts (colonialism as active erasing, writing, and re-writing of spatial relations on the surface of the globe as if it were formerly entirely blank). ${ }^{15}$ In the case of the latter, the Age of Exploration saw the expansion of the colonial territory and the extension of the governing arm of European empires into other parts of the world as an act which, if understood cartographically, involved the attempt to chisel into that blank, piece by piece, to slowly but surely cover that terrestrial skin with colonial ink. The colonized space posed as a body whose exteriors were assumed to be a mappable terra incognita-erotic, alluring, and demanding attention-a space in need of colonial order, waiting to be surveyed and overwritten with a new set of toponyms, recognizable and pronounceable for modern Western subjects. To the same effect, promising permanence while eventually falling victim to fits of fragility like any other object, slated globes allowed future agents of the US Empire to experiment with the spatial representation of such a world as a geographical expanse that was both desired and imagined to be blank, mappable, erasable, and pliant.

And yet, there is a "but" to ponder here: According to Roland Barthes, it is not the blank itself but the difference that always remains between the already-written-on 
surface (the expanding grip of Western spatial dominance surveyed, mapped, and named, the terra cognita) and the yet-to-be-written-on surface (the terra nondum cognita) that leads to a somatic, Epicurean, sensual quality in any surface (10). Barthes likens this lag and its resultant lure to "the intermittence of skin flashing between two articles of clothing (trousers and sweater), between two edges (the open-necked shirt, the glove and the sleeve); it is this flash itself which seduces, or rather: the staging of an appearance-as-disappearance" (10). Without this contrast of the known and the unknown, the juxtaposition of the written and the to-be-written, the philistine posited against the civilized, the blank is deemed dull, banal, even nonexistent.

If blank charms and tempts only when placed in a nexus with what is already unmasked, if it triggers a youthful wish to grow older and discover what stands outside of the known and the civilized only when coupled with the mapped and named and occupied, then how did a complete blank in the form of black, tabletop, slated globes manage to capture the fascination of American geographers and pupils? If, as Harley contends, maps have historically been considered "privileged knowledge" (88), then what did the American youth of the early to mid-twentieth century see when faced with the total blankness of a slated globe that promised to quench their thirst for both knowledge and privilege ${ }^{16}$ Where on the blank surface of a slated globe would a twentieth-century American pupil place her finger and quote Heart of Darkness's Marlow?

21 My response to these questions is threefold: first of all, if we continue to take these blank globes as simple representations of the classic terra nondum cognita of the Age of Exploration, then the pedagogic use of slated globes would rather neatly correspond with the times' understanding of the blank state of a child's mind, at least when first learning about and encountering the world at large. This would in effect fit the primary educational purpose of slated globes (as set by cartography companies), resulting in their gradual popularity over time, because similar to the supposed tabula rasa state of the human brain upon birth, the terra incognita of the Age of Empire too was a temporal category that was expected to diminish over time, a "not-yet" of perspective-"a way of foretelling future knowledge, of submitting... to a particular temporality, that of the perfectibility of knowledge and the linear and continuous progress of discovery" (Jacob 264). During the Age of Empire, Africa, for instance, was a massive terra incognita only from the perspective of Europeans and only up until the moment when European cartographers decided that they were done mapping and partitioning it. In a similar manner, and at least at the beginners' level, that is, $4^{\text {th }}$ through $6^{\text {th }}$ grades, slated globes were effective tools that could lessen young children's confusion in encountering the fully cognita, terrestrial globe by parsing out the excess of data on its surface and dehierarchizing the terra cognita and terra incognita at the service of geographical education.

Second, given that slated globes were recommended as tools to teach geography to American children at all levels, from beginner to advanced, these globes could be viewed at more advanced levels of geography teaching in terms of their capacity to counter the fascination of the times with the fully-mapped world of European empires. There is no doubt that blank does not necessarily signal an absence, but rather the illusion thereof. Similar to the external reality of Africa or the Americas, which were far from blank before Europeans began to survey and map their various parts, slated globes too were never fully free from the dictates of the very history that baptized them as tools of empire before they were put to use by school children. In effect, to 
better respond to the questions posed above, it is imperative that we remind ourselves that, when put to use as an educational artifact, the blank surface of slated globes was inevitably already haunted by the ghosts of previous acts of mapping as if it was the same terrestrial globe that had yielded to blankness due to the excess of visual matter violently covering its surface. In essence, then, the surface of slated globes was entirely cognita, neither un- nor de-colonized. In other words, slated globes' blank surfaces, far from being vacant, were overflowing with cartobibliographic material (transportation routes, borderlines, colors, place-names, scalar miscalculations), and masked through multiple acts of cartographic (un)doing every time the outline of a continent was drawn and erased and every time a teacher put a student's memory to test. And the gap between the repeatedly recorded known that was accessible through comparison to other maps and globes and the presumed unknown that was waiting to be drawn, named, and then erased on slated globes was filled with chalk dust, youthful trepidation, didactic frustration, occasional playful doodles, and stern imperial ideology.

Based on this, we could distinguish the blank offered by slated globes from the one entailed in terrestrial globes and world maps. Viewed from this angle, what can be discerned is that, determined to restore the power and allure of the blank as it was fast disappearing, American geographers took advantage of this moment in order to establish a different kind of blank: unblemished by the European touch, this was not the same old terra nondum cognita of the Age of Reconnaissance, but a seamless terra incognita iterum-the coming back of a blank of an unprecedented nature that was the product of a different historical moment. Not entirely antonymous to the traditional notion of terra incognita, the terra incognita iterum departed from the very existence and quality of the terra nondum cognita. This new terra incognita recorded pristine world orders. To be precise, the terra incognita iterum was a means of learning how to draw and control, one that translated erasure-of traditional Western scientia mundi-not into want of cartographic knowledge but rather into spatial re-investment, as it gave American youth the power to re-possess the world at the dawn of a century that was later styled both as the American and the geographic century (Smith 7).

In other words, in a colonial setting acutely fraught with anxieties about loss of domination over the colonized space and about putting their dominion on display through maps and globes, slated globes' emptiness did more than inviting fantasy; rather, it provided the ground for absolute and boundless dominion, the ground for the rise of a global power. In this light, the terra incognita iterum is different from the original terra incognita in that it could be called upon as a modern spatial fix to the already overly and overtly known, the terra seemingly seamlessly rendered cognita, a colonially homogeneous space possessed by European imperial states. Terra incognita iterum entailed an as-if call to new imperialists to treat the world ambivalently as a globe and a blackboard and to renew colonial spatial efforts to navigate, know, name, and narrate.

25 Underlining the significance of tactile cartographic didactics for the mostly untraveled, young American students of world geography, and speculating on the range of possible effects emanating from the "physical relationship between the individual and the map" (Edney 24), what made these objects effective educational tools was that they enabled American youth, future stewards of the US Empire, to in fact learn how to (re-)colonize the terra that was already made cognita by Europeans without stepping away from their 
desks and to engrave the surface of the earth without having observed it firsthand. Provoking, in equal measure, playfulness and patriotism, slated globes were washed of imperial colors, and freed of the border lines imposed on them, drained of water and emptied of landmasses, only to be scathed, and tattooed with lines, colors, and names, watered and landed-in sum, to be "globed" in the hands of the young American learners of world geography.

Third and finally, to further respond to the doubt cast upon the allure of the blank surface of slated globes, I would like to turn to the insights offered by the president of the Association of American Geographers at the time when slated globes were at the peak of their popularity, that is, the middle of the twentieth century. As John K. Wright (3) argued in his now classic, 1947 presidential address, "Terrae Incognitae: The Place of the Imagination in Geography":

Indeed, if we look closely enough-if, in other words, the cartographical scale of our examination be sufficiently large-the entire earth appears as an immense patchwork of miniature terrae incognitae. Even if an area were to be minutely mapped and studied by an army of microgeographers, much about its geography would always remain unknown, and, hence, if there is no terra incognita today in an absolute sense, so also no terra is absolutely cognita.

In Wright's observation, by the mid-twentieth century, absolute terra incognita was nowhere to be found, at the same time that the absolute terra cognita did not exist either. Considering the questions of distance and scale, we can conclude that, no matter where we direct our gaze, the closer we get to the terra cognita on the surface of the earth, the more visible and troubling (to the colonizer's confidence) the incalculable number of personal, domestic, privatized, or imaginary terrae incognitae that we spot. As Wright further clarified: "Behind us has lain the valley out of which we have come, the farm or ranch where we have sojourned. Before us has spread, if not a land unknown to the United States Geological Survey, at least a personal terra incognita of our own" (Wright 1).

In this sense, it is important to note that, from the perspective of mid-twentieth century world geography, terra incognita and terra cognita have never been mutually exclusive, binary opposites. The known and the unknown, though hardly admitted by colonizers just a few decades before Wright made these observations, could not be separated, nor could their blanketing effect in shaping individuals' geographical imaginaries be clearly marked. From this perspective, what is discernible is that terrestrial globes were not fully cognita, just as their slate siblings failed to offer a total blank. Instead, each functioned as a proxy for the other for American children to make sense of the world. In the case of common terrestrial globes, the explosion of placenames and borderlines created the illusion that no terra incognita was to be found anymore. In the case of slated globes, on the other hand, the total blank they offered would result in the illusive notion that students could essentially imagine the world anew, while a careful juxtaposition of the two globes together at the more advanced levels could cast serious doubts on these illusions altogether.

Thus, slated globes do not denigrate the known in favor of the unknown, nor do they simply conflate the known and the unknown. More complexly than that, these modern artifacts were charged with cartographic significance only once they entered a complementary matrix created around the previously existing cartographic knowledge of the world. The cartographer, the school teacher, and the pupil appropriated the terrestrial globe as a spatial palimpsest, invoking varying degrees of known and 
unknown as they erased, drew, and erased again: once put to proper use, the 1955 catalog of the Denoyer-Geppert Company insisted, "this globe becomes a living thing, made so by the interplay of minds, teachers' and pupils"' (Geppert 8). In effect, if we agree with Wright that in late modernity we understand all terra to be an intermittent conglomeration of the cognita and the incognita, then the comparatively younger American colonizers could decide which terra to focus on in isolation, keeping the rest conveniently covered under the blanket of blankness. After all, allowing for uncertainty, inaccuracy, and partiality of perspective, despite the urge to know it all and own it all, is an essential feature of the modern global environment.

\section{Conclusion}

As I demonstrate here, slated globes were objects with both a past (their intended educational purposes that they shared with terrestrial globes, cradle globes, etc. once they appeared in classrooms) and a present (their potential, intended and unintended, repertoire of uses on the hands of individuals who came to work with them)-a life that was uniquely their own. ${ }^{17}$ Standing against the dominance of horror vacui over then conventional cartographic practices, they further opposed the fascination of the times with the homogenized, fully mapped global. Far from being a finished goods, slated globes were plastic, imperial "practice fields" of world geography-(re-)inscribable objects that were both intimate to children's touch and pliant in the service of the shifting geopolitical interests of the outward-looking US Empire at the dawn of a new century. ${ }^{18}$

31 In hindsight, we can argue that slated globes stood for more than a mere protest against early twentieth-century pretensions to cartographic accuracy and scientific thoroughness. Indeed, at work at the nexus of the colonized and the colonizable spaces, calling into question the "apparent stability" and "aesthetic closure and finality" of world projection maps and terrestrial globes (Cosgrove 2), slated globes mediated between the distrusted but undoable cartographic knowledge that had resulted from previous acts of colonizing and mapping (the un-veiled known, the terra made cognita) and a recalled, as-if, evasive, re-colonizable unknown (the re-veiled known, the terra incognita iterum) that the US Empire desired upon its entry into the global market of colonization. Departing from existing cartographic modus operandi for the sake of establishing a new global imaginary-an imaginary that would best fit the imperatives of the US rise to global empire at the dawn of a new century-these artifacts allowed for a new mode of world cartography, a modern spatial fix that I refer to as "globing."

Reading slated globes in their US context of use, these blank globes materialized Americans' desire to imagine the world as terra incognita through and through, in the spirit of what Arjun Appadurai characterizes as a "plurality of imagined worlds" (5). While there is no guarantee that every American pupil growing up at the turn of the twentieth century learned geography with the use of a slated globe, and while British or German teachers and students might have used slated globes entirely differently, we can safely conclude that, in reference to individual or collective understandings of the "world"-beyond the version already endorsed by those in power as the one and only visual narrative of the world-slated globes offered a heuristic, a reminder that-once espoused with geopolitical imperatives of this or that empire-geographic knowledge is 
inevitably conditional, shifting, provisional, partially futuristic, and, most importantly, palimpsestically plural.

\section{BIBLIOGRAPHY}

Akerman, James R. "Introduction." The Imperial Map: Cartography and the Mastery of Empire, edited by James R. Akerman, U of Chicago P, 2009, pp. 1-9.

Appadurai, Arjun. Modernity At Large: Cultural Dimensions of Globalization. U of Minnesota P, 1996.

Barnard, Henry. "Slate Globes and New Slates." The Connecticut Common School Journal, vol. 14, no. $10,1859$.

Barth Volker, and Roland Cvetkovski. "Encounters of Empires: Methodological Approaches." Imperial Co-operation and Transfer, 1870-1930: Empires and Encounters, edited by Volker Barth and Roland Cvetkovski, Bloomsbury Academic, 2015, pp. 7-14.

Barthes, Roland. The Pleasure of the Text, translated by Richard Miller. Basil Blackwell, 1990.

Brückner, Martin. The Geographic Revolution in Early America: Maps, Literacy, and National Identity. U of North Carolina P, 2006.

Burrell, Carolyn. "Cradle Globes in the USA: A Short Overview.” Globe Studies, vol. 51-52, 2005, pp. 109-126.

Burrows, Frank Robert. Geographical Gleanings. George Philip and Son, 1906.

Chaves, Kelly K, Oliver Walton, Jay H. Buckley, and Jeffery D. Nokes. Explorers of the American East: Mapping the World Through Primary Documents. ABC CLIO, 2019.

Cosgrove, Denis E. Mappings. Reaktion Books, 1999.

Davis, Lloyd. Virginal Sexuality and Textuality in Victorian Literature: Essays in Environmental Philosophy. SUNY P, 1993.

Davis, Noah K. Alabama Educational Journal, vol. 1, no. 3, December 1858.

Du Bois, W. E. B., and Eugene F. Provenzo. Du Bois on Education. Rowman and Littlefield, 2002.

Edney, Matthew H. “The Irony of Imperial Mapping.” The Imperial Map: Cartography and the Mastery of Empire, edited by James R. Akerman, U of Chicago P, 2009.

Geppert, Otto E. "Suggestions for Use of the Slated Outline Globe." Better Understanding and Use of Maps, Globes, Charts. Denoyer-Geppert Company, 1955.

"Geography and Astronomy." Catalogue of the Educational Division of the South Kensington Museum. George E. Eyre and William Spottiswoode, 1867.

Giles-Watson, Maura. "Female Body as Geosomatic Apotrope in Chaucer, Shakespeare, and Middleton." Mapping the Premodern Selected Proceedings of the Newberry Library Center for Renaissance Studies $26^{\text {th }}$ Graduate Student Conference, edited by Karen Christianson, The Newberry Library, 2008, pp. 39-48.

Goldstein, Alyosha. Formations of United States Colonialism. Duke UP, 2014. 
Greenberg, Amy S. Manifest Manhood and the Antebellum American Empire. Cambridge UP, 2005.

Gruesser, John Cullen. The Empire Abroad and the Empire at Home: African American Literature and the Era of Overseas Expansion. Georgia UP, 2012.

Harley, John Brian. The New Nature of Maps: Essays in the History of Cartography. Johns Hopkins UP, 2002.

Hughes, Kathryn. "The Figure of the Governess." Discovering Literature: Romantics and Victorians. British Library, 15 May 2014, accessed 22 Dec. 2019.

https://shar.es/aHET60

"Inventions for Schools: Slated Globes." The New York Teacher and American Educational Monthly, vol. 5, June 1868.

Jacob Schem, Alexander, and Henry Kiddle. The Cyclopcedia of Education: A Dictionary of Information for the Use of Teachers, School Officers, Parents, and Others. E. Steiger, 1876.

Jacob, Christian. The Sovereign Map: Theoretical Approaches in Cartography Throughout History. U of Chicago P, 2006.

Jameson, Fredric. Postmodernism, or, The Cultural Logic of Late Capitalism. Duke UP, 1991.

Kaplan, Amy. The Anarchy of Empire in the Making of US Culture. Harvard UP, 2002.

King, Charles F. Methods and Aids in Geography for the Use of Teachers and Normal Schools. Lee and Shepard, 1897.

Knight, Edward H. Knight's American Mechanical Dictionary Volume II. Hurd and Houghton, 1876.

Locke, John. An Essay Concerning Humane Understanding. Eliz. Holt for Thomas Basset, 1690.

---. Some Thoughts Concerning Education. 1693. Scholar Press, 1970.

Maynard, Samuel. A Concise Introduction to the Knowledge of the Globes. Longman, Brown, \& Co., 1846.

McGranahan, Carole, and John F. Collins, editors. Ethnographies of US Empire. Duke UP, 2018.

Mokre, Jan. Rund um den Globus: Über Erd- und Himmelsgloben und ihre Darstellungen. Bibliophile Edition, 2008.

Monmonier, Mark. Coast Lines: How Mapmakers Frame the World and Chart Environmental Change. U of Chicago P, 2008.

O'Rourke, Karen. Walking and Mapping: Artists as Cartographers. MIT UP, 2013.

Pearson Alastair W., and Michael Heffernan. "Globalizing Cartography? The International Map of the World, the International Geographical Union, and the United Nations." Imago Mundi: The International Journal for the History of Cartography, vol. 67, no.1, 2015, pp. 58-80.

Ramaswamy, Sumathi. Terrestrial Lessons: The Conquest of the World as Globe. U of Chicago P, 2017.

Rand McNally and Company. School and Library Globes. Rand McNally and Company, ca. 1910s.

Reddleman, Claire. Cartographic Abstraction in Contemporary Art: Seeing with Maps. Routledge, 2018.

Rice, William. Journal of Education: A Monthly Record and Review, vol. 28, March 1906.

Rusling, James F. “Interview with President William McKinley.” The Christian Advocate, vol. 22, January 1903. 
Schumacher, Frank. "Embedded Empire: The United States and Colonialism." Journal of Modern European History, vol. 142, 2016, pp. 202-224.

Smith, Neil. American Empire: Roosevelt's Geographer and the Prelude to Globalization. U of California P, 2004.

Sponberg Pedley, Mary. The Commerce of Cartography: Making and Marketing Maps in EighteenthCentury France and England. U of Chicago P, 2005.

Suggested Books for Indian Schools; an Annotated List Which Includes Library Books, Recommended Textbooks, Reference Material, and Maps, Selected with Special Reference to the Interests and Activities of Rural Communities. United States Bureau of Indian Affairs, 1959.

Susan Schulten, The Geographical Imagination in America, 1880-1950. U of Chicago P, 2001.

"Sustained Use Simplified Teaching Tools: An Introduction to the Fascinating Study of Maps." Social Studies for Teachers and Administrators, vol. 42, no. 8, December 1951.

Swinton, William, Martin Grove Brumbaugh, and Vernon Llewellyn Davey. Grammar-School Geography: Physical, Political, and Commercial. American Book Co., 1896.

Tyrrell, Ian, and Jay Sexton, editors. Empire's Twin: US Anti-imperialism from the Founding Era to the Age of Terrorism. Cornell UP, 2015.

Wharton, Annabel. "Doll's House/Dollhouse: Models and Agency." Journal of American Studies, vo. 53, no. 1, 2019, pp. 28-56.

Wilford, John N. The Mapmakers: The Story of the Great Pioneers in Cartography, from Antiquity to the Space Age. Pimlico, 2002.

Wright, John K. "Terrae Incognitae: The Place of the Imagination in Geography." Annals of the Association of American Geographers, vol. 37, no.1, 1947.

\section{NOTES}

1. I am grateful to the staff of the International Coronelli Society for the Study of Globes for their assistance with accessing their collections online. I am further grateful to the staff of the Newberry Library and the Library of Congress who helped me with finding archival material at the time when-as a result of the 2016 travel ban (Executive Order 13769)-I could not travel to the United States to conduct further archival research myself. I also wish to thank Stephen Morgan, Niko Rohé, Rodrigo Marttie, and the anonymous EJAS reviewers for their insightful suggestions on earlier drafts of this essay.

2. At the start of the twenty-first century, slated globes are known merely as "chalkboard globes." Either bought ready-made or slated by individuals who are interested in DIY, they no longer belong to schoolrooms but rather to the idle collection of objects that stand on a living room sideboard. They are mentioned in passing, if at all, in coffee-table books on the history of western cartography, or in encyclopedias and museum publications on their holdings. Whether used to teach geography in the nineteenth and twentieth centuries or adopted to do collage work or to playfully draw travel itineraries in the twenty-first century, however, these woefully understudied objects seem to have had great appeal both in Europe and the United States. No doubt, the didactic function of these artifacts has been superseded over time by their adaptation as items of decoration, and yet, looking back at the settings in which they were originally put to use reveals their political birthmark. This is what this article sets out to do. 
3. Like any other tool, slated globes too were used in a number of scripted and unscripted ways. After all, as Annabel Wharton (48) maintains, regardless of the original intentions envisioned by its producers and of the many intended and unintended uses that it is put to by its consumers, an object's functions and uses are ultimately "conditioned by its context." Here, it is the context of the US Empire that informs my reading of the US-made slated globes over the course of almost a century.

4. Having found its way to the other side of the Atlantic too, Shepherd's invention was noted in England, for instance, in the 1867 Catalogue of the Educational Division of the South Kensington Museum (334).

5. Reflective of the differences between the ways the young US Empire and the long-lived British Empire approached and appropriated slated globes, one outstanding difference that sets USmade slated globes apart from their British counterparts is that-whether introduced in patent documents or endorsed in journals of geography-American slated globes were used to teach "a representation of the geography of the world" as a whole while their British siblings were recommended to be used in teaching "the position of the principal places on the surface of the Globe [emphasis added]" (Maynard 73).

6. See, for instance, "Inventions for Schools: Slated Globes," in The New York Teacher and American Educational Monthly, vol. 5, June 1868, 204.

7. Another set of geographical globes that appeared both in American schoolrooms and war rooms are "cradle globes." Originally invented by the Austrian globe-maker Richard Haardt in the mid-1930s, this axis-free globe appeared in the United States by the 1940s. As Carolyn Burrell (111-112) establishes, whether copied from Haardt's globes or not (he had called his axis-free globes "roll globes"), in vogue well after the Cold War era, American cradle globes first gained popularity during the WWII and as the nation developed a keen interest in air travel especially to the poles.

8. According to Davis (236), while Moore and Nims sold their terrestrial and celestial globes for $\$ 75$, their 16 -inch and 30 -inch slate globes cost respectively $\$ 12$ and $\$ 40$.

9. Also known as the "International Map of the World" or the IMW, Albrecht Penck's Millionth Map (called so after its 1:1,000,000 scale) was first proposed by the German geomorphologist in 1891. Introduced to and rather immediately adopted by the international community early in the twentieth century, the project was planned to consist of 2,500 maps that were drawn individually (but using one standard cartobibliographic language) by various national cartography organizations across the globe, with the hope of reaching a viably consistent map of the world.

For a thorough examination of this promising but ultimately aborted world cartography project, see Monmonier, Coast Lines, pp. 86-101, and Pearson and Heffernan, "Globalizing Cartography?," pp. 58-80.

10. For an excellent work on the crisis of imperial legitimacy, see Barth and Cvetkovski, “Encounters of Empires," pp. 7-14, and Schumacher, "Embedded Empire," pp. 202-224.

11. Detailed records exist of countless occasions at which European and American statesmen, mapmakers, and educators speculated about the right amount of cartographic data and topographic information to be included in maps and globes. For an inventory of instances of such debates in Britain and France, see Sponberg Pedley, The Commerce of Cartography, pp. 159-197.

12. See Wilford, The Mapmakers, p. 253.

13. "Tabula rasa"-the belief that human brain is a blank slate unto which impressions can be made through parenting, education and other forms of exposure-is one of the most well-known examples of blank popularized in the wake of the European Enlightenment. Though never referred to by John Locke in these words, the idea of tabular rasa is generally traced back to his educational writings, including An Essay 
Concerning Humane Understanding and Some Thoughts Concerning Education. See Locke, An Essay Concerning Humane Understanding; and Locke, Some Thoughts Concerning Education.

An outstanding twentieth-century example of the metaphoric use of blank in the West is found in the work of the Algerian-French artist/activist Fred Forest, such as his series of projects called Space Media that he created during the 1970s and his curated blank-signs demonstration against political oppression in Brazil during the twelfth São Paulo Biennial in 1972. For a detailed examination of Forest's art/activism, see O’Rourke, Walking and Mapping, pp. 20-23.

14. The marginalized and disempowered figure of the female has time and again been rendered 'blank' in western literature. As Lloyd Davis points out, in a wide range of literary renderings, the female body "is figured as a blank page, as virginal space, to be inscribed by the pen of the authorial and authorizing male" (50). In a remarkably incisive examination of the literary female as cartographically disempowered, Maura Giles-Watson refers to the female body in classic British literature as "geosomatic." Related to this is the image of other groups of individuals like governesses, maids, and servants, or non-female, infantilized African American slaves who have repeatedly fallen victim in literature and political discourses to the disempowering effects of being deemed blank. See, for instance, Hughes, "The Figure of the Governess."

15. Examples abound of such a viewpoint in the discourses on colonial cartography during the Age of Empire. For illuminating discussions about cartographic blank, see, for instance, Harley's discussion of the various meanings and uses of "silence" on cartographic maps in his work on history of cartography in the West. The discussion appears in Harley (86), where he emphasizes that he intentionally promotes "silence" as a preferable alternative to "blank" because of the human agency that the former implies.

Further discussion on the politics behind cartographic blank is made by Sponberg Pedley. For a discussion of "silent" maps and their uses in teaching geography, see Jacob, The Sovereign Map, pp. 354-360.

16. If, as Claire Reddlean maintains, we in fact "see with maps" (1), then the question here turns out to be: what is there to see when the whole globe is blank?

17. A thorough account of cradle globes and their origins appears in Burrell, "Cradle Globes in the USA."

18. This of course is not meant to write off the long imperial history of the United States before 1898 in its violent policies toward Native Americans or to treat the Spanish-American War as an aberration in US foreign policy. To the contrary, as Amy Kaplan (1) contends in her now-classic work The Anarchy of Empire in the Making of US Culture, I insist that twenty-first century scholarship on US Empire has to attend to the conflated proximity of the many imperial theaters the United States orchestrated throughout the nineteenth century in order to understand the ways "international struggles for domination abroad profoundly shape representations of American national identity at home, and how, in turn, cultural phenomena we think of as domestic or particularly national are forged in a crucible of foreign relations."

Further illuminating works such as Neil Smith, American Empire: Roosevelt's Geographer and the Prelude to Globalization, Amy S. Greenberg, Manifest Manhood and the Antebellum American Empire, John Cullen Gruesser, The Empire Abroad and the Empire at Home: African American Literature and the Era of Overseas Expansion, Alyosha Goldstein, Formations of United States Colonialism, Ian Tyrrell and Jay Sexton, Empire's Twin: US Anti-imperialism from the Founding Era to the Age of Terrorism, and Carole McGranahan, John F. Collins, Ethnographies of US Empire, provide access to the many contours of US Empire at home and abroad. 


\section{ABSTRACTS}

Manufactured by leading American globe-making companies, slated globes were adopted in the second half of the nineteenth century as educational aid materials, recommended for teaching world geography from the $4^{\text {th }}$ grade on. Focusing on their production and use in the US context at the turn of the twentieth century, and following an examination of their role in teaching American children the fundaments of terrestrial geography, I probe these now forgotten, blank, black, educational table globes' capacity in offering a timely "spatial fix" to the prosaic finality of an already overly and overtly known world that the globally rising US Empire was grappling with. Provoking, in equal measure, playfulness and patriotism, I argue, slated globes were washed of imperial colors and freed of the border lines imposed on them, drained of water and emptied of landmasses, only to be once more scathed, and tattooed with lines, colors, and names, watered and landed-in sum, to be "globed" in the hands of the generations of American youth, future stewards of the US Empire who were learning how to (re-)imagine the terra that was already made cognita by earlier colonial powers. Furthermore, I read slated globes as generative of terra incognita iterum (territory made unknown again) - a terra incognita of a different kind and for different purposes than the terra nondum cognita (territory yet unknown) of the previous centuries: a blank fraught with colonial urges of a young empire and charged with imperial pedagogics.

\section{INDEX}

Keywords: slated globes, terrestrial globes, imperial pedagogy, US empire, cartographic blank, terra incognita, globing, terra incognita iterum, school geography

\section{AUTHOR}

\section{MAHSHID MAYAR}

A literary critic and cultural historian, Mahshid Mayar is an assistant professor of American Studies at Bielefeld University, Germany. She is currently working on her second-book project where she studies "blank" and "erasure" in postmodern American literature, while she also conducts research on US empire, historical childhood studies, and critical game studies. Mahshid's first book, Citizens and Rulers of the World: American Children and World Geography at the Turn of the 20th Century, is under contract with the University of North Carolina Press. 